\title{
Navegando da Arrábida a Porto Seguro ${ }^{1}$
}

Cleonice Berardinelli

É com imensa alegria que me vejo reintegrada nos cursos da Arrábida, desta vez na qualidade de conferencista, para encerrá-los, começando por agradecer a quem aqui me trouxe: o meu amigo Eugénio Lisboa, diretor dos cursos, que quis agraciar-me com uma dupla condecoração: a de ser uma das pessoas que abrem e fecham estes já notórios encontros e a de ter sido posta em "pendant" com a grande escritora brasileira e minha cara amiga, Nélida Piñon.

O convite que recebi por e-mail não me esclarecia sobre a natureza do que se esperava da minha fala. No que lhe mandei em resposta, além do agradecimento comovido, ia a pergunta: Sobre quê deveria falar? Sobre o que quiser, respondia-me o amigo, mas acrescentava: Talvez sobre os cursos, quem sabe?, sobre os 500 anos de Brasil?... Desta vaga proposta me ficaram desenhados na mente dois espaços: o dos cursos - a Arrábida - e o das comemorações - a Terra de Santa Cruz que fixei, inconscientemente, em Porto Seguro.

Dias mais tarde, novo e-mail e a pergunta fatal para todos nós que participamos, com bastante freqüência, de encontros universitários: E o titulo da conferência? Primeira resposta, dilatória: Ainda não o pensei. Dê-me, por favor, quarenta e oito horas de praz̧o. Quarenta e oito horas de aflição, de hesitação; enfim, uma decisão, quase fugindo pela tangente: um título impreciso, prometendo muito, provavelmente não realizando senão um pouco, mas que me restituiu por algum tempo a tranqüilidade, sempre tão precária... Já o conhecem, mas repito-o: Navegando da Arrábida a Porto Seguro.

A pergunta que vos estais fazendo agora, estranhando essa viagem entre pontos tão inesperados, fiz-ma eu, quando comecei a escrever estas linhas com que pretendo atrair e manter a vossa atenção, sem maçar-vos. E quem ma sugeriu foi o próprio Eugénio Lisboa, que passa a ser, desde este momento, responsável pelo sucesso ou insucesso da navegação. Não foi ele que me disse que falasse sobre os cursos, sobre as comemorações do descobrimento? Já não vos disse que da sua resposta me ficaram sobretudo dois espaços marcantes, definidos? Pois é deles que falarei: a viagem fica num terceiro espaço, do imaginário; o trajeto, não o fiz por barco, no mar oceano nunca doutrem navegado, mas levada nas asas da imaginação, num mar de memória e afeto, sem bússola ou sextante, sem astrolábio, sem cartas de marear. Desta viagem, tão abstrata, nem esta navegadora vos poderia ou saberia falar. Falará dos pontos extremos, a que aportou com séculos de permeio, que descobriu com óculos de médio e longo alcance, que a seduziram de modo vário. Vós a acompanhareis na viagem - que, em verdade, não fez; se conseguir sentir-vos ao seu lado na Arrábida e à roda de Porto Seguro, se puder comunicar-vos algo da sua/ minha emoção de neles estar ou supor estar, terei a impressão de não ter traído a confiança em mim depositada por Eugénio Lisboa.

Convidada a pronunciar uma conferência, começo por dizer-vos que prefiro chamar-lhe palestra: conferência parece-me algo mais formal e formalizado, algo em que eu 
deveria desenvolver assuntos que tenho o dever de dominar, depois de tantos anos a eles dedicados, anos de honesto estudo e longa experiência. Farei, pois, uma palestra - recuperando, nesta palavra de origem grega, o sentido primitivo de lugar onde a gente se adestra à luta, passando pelo que lhe atribui Horácio, adjetivando-a: palestra decora, a luta que traz a beleza, já então significando entre os latinos escola e letras e vindo a ser, em português, sinônimo de conversa, onde permanece a idéia de espíritos que se chocam, se enlaçam e se despertam na vivacidade irrequieta do diálogo ${ }^{2}$. Numa palestra me sinto mais à vontade para transmitir-lhes, através de um texto compósito, retalhos de vida, que incluem a visitante de carne e osso, que se enamora da paisagem, a estudiosa da literatura portuguesa, que, tomada da paixão pelo texto, substitui a paisagem real pela paisagem ficcional e poética de uma écloga de mais de quatrocentos anos, a aprendiz de história, que se escuda nos especialistas da matéria para recuperar a sua bastante próxima origem portuguesa. Numa palestra não exigireis que eu tenha, nesses descaminhos, a competência com que trato, ou me esforço por tratar, os assuntos que constituem a matéria de meus cursos, ensaios e verdadeiras conferências. Com o desejo de que, ao calar-me, se estabeleça entre nós uma palestra em seu sentido total, que nos estimule reciprocamente, retorno ao ponto inicial da viagem, à Arrábida e, já que lhes disse, com certa ênfase, que esta navegação se fará, sobretudo, no imaginário, por que não considerarmos que esta sala em que estamos, no encerramento simbólico dos cursos da Universidade de Verão da Arrábida, é, pela simbologia que encerra, Arrábida também?

Se concordardes, poderei dizer que nesta estou, pessoalmente, pela terceira vez. A segunda, bastante recente, foi em julho-agosto, há menos de dois meses, no excelente curso organizado por minha colega da UFRJ, Profa. Gilda Santos, intitulado Brasil e Portugal: 500 anos de enlaces e desenlaces no qual falei sobre o belo e duradouro enlace, implícito ou explícito, de Manuel Bandeira com a literatura portuguesa. E a primeira?

No clima de palestra, como dizia atrás, posso permitir-me fazer um pouco de autobiografia, quase inevitável quando já vai longa a caminhada pelos caminhos da vida. E aqui me ocorre lembrar, entre parênteses, a bela e vibrante apresentação do antropólogo Joaquim Pais de Brito - mais um que falou de enlaces -, que este iniciou dizendo que ia falar do seu trajeto individual, de sua dupla experiência - pessoal e intelectual. E de fato revelou-se aos nossos ouvidos e aos olhos da nossa imaginação um percurso rico, progressivamente enriquecido e enriquecedor, de uma sensibilidade inteligente - ou, se preferirem, de uma inteligência extremamente sensível -, seduzida pelos versos de "Morte e vida severina", pela música de Vínicius, pela ficção de Graciliano Ramos ou de Guimarães Rosa, pelo cinema brasileiro de Vidas secas e de Deus e o Diabo na terra do Sol. E não era só: sua curiosidade de pesquisador atento buscava relações entre o português e o brasileiro n'O cortiço, de Aluízio de Azevedo, a presença do fado como canto e dança em Memórias de um sargento de milícias, o estudo de João do Rio sobre o fado, a séria pesquisa de Câmara Cascudo sobre o folclore brasileiro.

Acompanhei até aqui o trajeto pessoal e intelectual de Joaquim de Brito, que me acudiu à mente ao dizer de mim mesma que iria permitir-me fazer um pouco de autobiografia. Creio que já estou justificada. Que passe a autobiografia. 
Há quarenta e um anos, meu marido e eu chegávamos pela primeira vez - e de navio - a Portugal. Eu acabava de prestar um concurso de livre docência - versão brasileira do que é, em Portugal, o exame de agregação -, que culminara com a defesa de uma tese sobre a poesia de Fernando Pessoa, a segunda que se escrevia no mundo: a primeira fora a de Jacinto do Prado Coelho. Eu saíra, onze dias antes, exausta, do porto do Rio de Janeiro. Onze dias de mar e céu, debruçada na amurada do navio, descobrindo, por minha própria conta, que a terra é redonda - já eu o aprendera desde os bancos da escola, já o vira em mapas e gravuras, em globos terrestres, mas a apreensão visível, sensível, quase táctil me tomava ali, na solidão das águas só limitadas pelo horizonte longínquo em que se tocavam o mar e o céu, numa linha harmoniosamente curva; onze dias estirada numa espreguiçadeira, lendo devagar e por puro prazer, ou braço no braço do marido, dando lentas voltas no convés, totalmente livres ambos de compromissos, degustando cada minuto de um repouso bem merecido.

Foi assim que, descansados e já desejosos de movimento, entramos o Tejo e chegamos a Lisboa, por onde começaria a nossa descoberta de Portugal, de um Portugal de que eu sabia de cor tantos sítios, tantas igrejas, tantos castelos, tantas paisagens, tantas falas, tantos versos, cuja história me era tão familiar, cujos filhos ilustres conhecia tão de perto, cuja cultura, havia àquele tempo quinze anos, procurava apaixonadamente divulgar.

À partida, a família e os amigos faziam-me prometer que lhes escreveria constantemente, para que nos pudessem acompanhar nos três meses de viagem. Àquele tempo, uma despedida no porto era longa, quase interminável, e havia tempo para se fazerem todas as exigências. Prometi e não quis descumprir a promessa. Para evitar ciúmes e possíveis injustiças, decidi ir descrevendo e narrando, paripassu, os caminhos e as andanças. Acabei por fazer um diário - o único da minha vida - a que consegui dar seguimento até que transpusemos as fronteiras de Portugal com Espanha. Desta, de França, Suiça, Alemanha, Itália, nada ficou gravado senão na memória e nas fotos que "o meu fotógrafo particular", como chamava a meu marido, fazia questão de tirar a cada parada, "para documentar", dizia ele. É deste diário que recupero, com cortes, alguma coisa do nosso dia 20 de março de 1959, no relato desataviado, sem preocupação literária, escrito por vezes no próprio carro que nos conduzia, ou no restaurante, enquanto aguardávamos a refeição:

O dia de ontem foi maravilhoso. Resolvemos ir a Évora de carro, passando pela Serra da Arrábida. No cais de Alcântara pusemos o carro na barca para atravessar o Tejo; andáramos até então no Ribatejo, íamos conhecer a Estremadura e o Alentejo. Passados para a outra margem, seguimos ao longo de uma estrada de segunda (asfaltada, mas de uma só pista), muito semelhante às que já tínhamos visto, atravessando aldeias e vilas que se sucedem quase sem interrupção. Nossa primeira parada seria Sesimbra, com sua linda praia. Quando já se avistava o lugarejo, vi à direita, bem no alto, um castelo medieval. Quis chegar mais perto e, apesar dos protestos do marido, valeu-me a boa vontade do motorista, que fez marcha à ré e subiu pela estrada estreita e pedregosa os $240 \mathrm{~m}$. de altura do pequeno monte. Como sempre, valeu! O castelo, que foi tomado aos mouros por D. Afonso Henriques (ao que nos disseram), conserva suas cinco torres, restauradas há pouco tempo. É uma imponente massa de pedra, de onde se descortina uma magnífica vista sobre o mar e sobre os campos. Fomos até onde havia escadas, demos a volta à muralha e nos extasiamos com o espetáculo. 
Descemos até à pequena e velha aldeia, disposta em semi-círculo paralelamente à praia. Os barcos de pesca haviam saído e só voltariam à tarde. Alguns pescadores enrolavam suas linhas embaraçadas ou consertavam as redes. Paz e silêncio reinavam...

De Sezimbra seguimos para Setúbal, subindo a serra da Arrábida, onde há talvez o mais belo panorama marítimo de Portugal. Eu já sabia disso, a serra foi várias vezes cantada pelos poetas, mas o real é ainda melhor. Sobe-se por uma estrada relativamente estreita, sinuosa; de um lado a serra, do outro, o mar, um mar verde como o do Joá, com praias de espaço a espaço, muito brancas, com grupos de casas novas e bonitas que vão subindo a encosta alcantilada. Há um ponto de extraordinária beleza, onde a costa é uma falésia a pique, $350 \mathrm{~m}$. acima do mar. Causa arrepios. No alto da serra, um miradouro, Formosinho (500 m.), de onde se avista, dizem, Évora, o Algarve e Lisboa. Na verdade vimos muito bem Lisboa e Sintra, uma mancha que deveria ser Évora, mas para o sul estava um pouco nublado. É um espetáculo em tons de verde: o campo, a mata, o mar... Descemos até Portinho da Arrábida. Uma praiazinha de brinquedo, com meia dúzia de casinhas velhas e pitorescas, uns barcos descansando na areia, um quiosque onde se vendem coisas de comer. Comprei de um pescador dois cavalos marinhos que, diz ele, dão sorte. Mas eu já tenho tanta...

Voltamos pela estradinha (que mal dá passagem a um carro) ao Formosinho, de onde rumamos à direita para Setubal.

Aí está, meus amigos, a breve história do meu primeiro encontro com a Arrábida, do meu encantamento pela Arrábida. Encontro em carne e osso, como disse de início. Teria havido, pois, um encontro anterior, ou encontros anteriores? Com certeza.

Ao estudar, com meu grande mestre Fidelino de Figueiredo, o século XVI, li autores de que tinha alguma noção ou mesmo alguma leitura, feita no curso secundário (aqui diria: no liceu). Um, de nome Cristóvão Falcão, me era totalmente desconhecido e logo me intrigou a dúvida lançada sobre a autoria de suas poucas obras que alguns atribuíam a outros poetas, principalmente a Bernardim Ribeiro. Uma delas, a que o notabilizou, a écloga Crisfal, encantou-me à primeira leitura: suas redondilhas maiores fluíam suavemente, bem medidas e bem rimadas, narrando comovidamente uma história de pastores unidos e separados por um amor infeliz, iniciada num espaço que pode ter existido apenas na imaginação do narrador/poeta, mas que para mim se constituiu em espaço do desejo - desejo de vê-lo com olhos de ver, não só de imaginar. A primeira estrofe do poema (ou copla, como se dizia então) se compõe de dez versos (ou pés) e é de notar-se que em tão pequeno espaço se dê um resumo, ou sinopse, total do poema: o espaço da narrativa (com detalhe), os seus personagens, a intensidade do amor que os uniu, os males que dele decorrerão, o desejo formulado pelo narrador de que tal sentimento nunca tivesse existido, a explicação do porquê deste desejo:

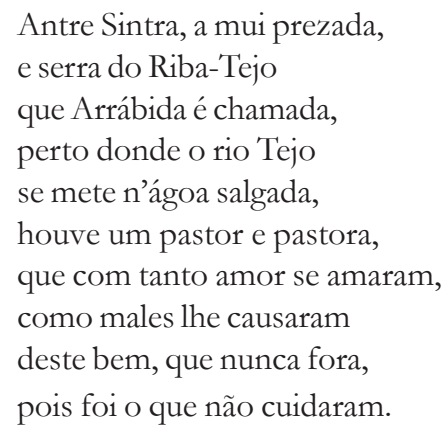


$\mathrm{Na}$ copla seguinte, outras informações: os nomes dos pastores, a sua pouca idade, a transformação da felicidade em infelicidade, a saudade como medida do amor:

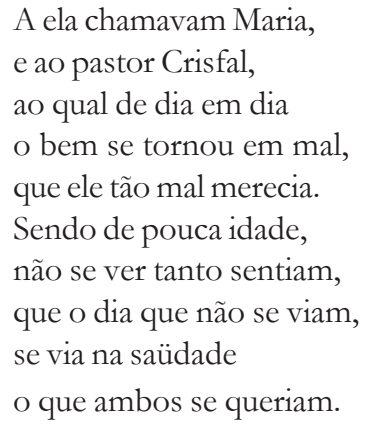

Em nove coplas ouvimos o narrador falar das tristezas que afligem o jovem par amoroso, porque a família de Maria a afasta para "longes terras" (como a Menina e Moça, de Bernardim). Confessa-se incapaz de exprimir o doloroso sentimento de Crisfal: decide transcrever-lhe as palavras com que lamentava a sua desdita amorosa, ao longo de mais dezoito coplas.

Já agora não é o narrador, mas o sujeito lírico do desabafo amoroso que se ouve, alternando a queixa exalada do fundo do coração e o relato da triste história que viveu e está vivendo. Sua solidão, talvez a abrande criando alocutários em si mesmo: seus olhos, as lágrimas que deles correm, o próprio coração, a quem dirige a palavra triste e harmoniosa. Também fala às águas, a quem passa a narrar um sonho que teve uma noite, cansado de sofrer e persuadido de que, se com ela sonhasse, abrandar-se-lhe-ia o sofrimento.

Em sonho, era erguido muito alto pelo vento e depois levado "antre Tejo e Odiana", vendo muitas cousas que passa a contar, todas elas relacionadas com amor. Ao amanhecer de mais um dia passado em tristeza e saudade, ouve uma voz feminina a cantar. Terminada a primeira cantiga, o narrador diz que se lhe seguiu outra que ele ouvia com encanto, só depois identificando-lhe a voz:

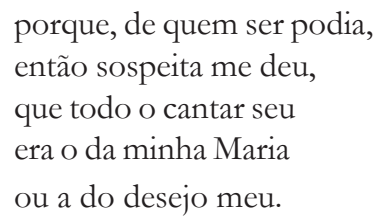

Ainda assim, estranhou o seu aspecto, as suas vestes quase pobres. Disse-lho e ela, em resposta e longamente, lhe contou o que ocorrera desde que se haviam separado. Um dolorido diálogo se estabelece entre ambos até que ela, cansada de tanto sofrer, o repele, pedindo-lhe:

"Não te veja aqui ninguém; vai-te, Crisfal, desta terra; não quero teu querer-bem, 
porque me não dê mais guerra

da que já dado me tem."

Desesperado, cai por terra como morto; ao voltar a si, encontra-a ao seu lado, a dizer: Ó mesquinha! / como pude ser tão crua!, crueza que corrige com a atitude apaixonada:

bem abraçado me tinha,

a minha boca na sua

e a sua face na minha.

Lágrimas tinha choradas, que com a boca gostei,

mas, conquanto certo sei

que as lágrimas são salgadas,

aquelas doces achei.

Esta bela passagem, ousadamente erótica, foi tomada como argumento dos que defendiam a autoria de Cristóvão Falcão. Não se encontra em Bernardim uma cena de amor com esta carga de sensualidade.

Maria convence-se da fidelidade de Crisfal:

Eu sei bem que não me mentes,

- que o mentir é diferente;

não fala d'alma quem mente;

Crisfal, não te descontentes,

se me queres ver contente.

e conclui, justificando-se, em estilo que eu classifico como agudo e engenhoso:

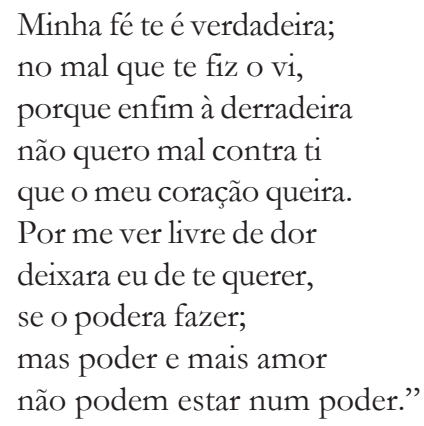

Neste passo acordei eu, diz Crisfal. E o ver que tudo não passara de um sonho causalhe tal tormento qual nunca cousa me deu. É ainda a vOz do pastor que ouvimos nas três coplas seguintes, a última das quais não consta da primeira edição conhecida, a de Arnold Birckman, de 1559. Epifânio Dias, que nos deu em 1893 uma edição crítica da écloga, diz em nota: Esta estancia, se é de Christóvão Falcão, foi provavelmente omittida em redacção posterior; em todo o caso parece que a nenbum respeito faria falta na ecloga. Discordo do eminente mestre, sem que em nada diminua o respeito e admiração que tenho por sua obra de editor e anotador exímio. Cito a copla: 


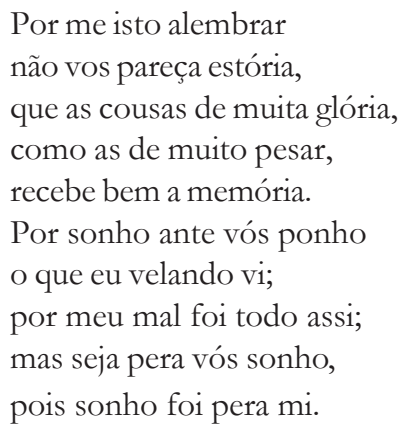

Começo por apontar uma curiosidade lingüística: a utilização da forma já então quase esquecida, estória, com o sentido de coisa inventada, para se opor a história, que começa a ter, ainda em grego, e em Heródoto, o sentido que tem hoje. O folclorista brasileiro Luís da Câmara Cascudo reintroduziu "na linguagem do folclore e das ciências humanas em geral, a variante popular e arcaica exatamente para designar, especificamente, os contos, narrativas, tradições e lendas do povo". (A. G. Cunha). Adotou-a o grande Guimarães Rosa, chamando a dois de seus livros Primeiras estórias, Terceiras estórias.

É com esse significado que a encontramos na écloga que vimos acompanhando. Crisfal, em suas últimas palavras, encarece a verdade do seu conto: não vos pareça estória, não pareça coisa inventada esta história tão triste, da qual, como Camões, poderia ter dito: Oxalá foram fábulas sonhadas! Tal como foi, como existiu, guardou-a a memória, que guarda o que dá muita glória ou muito pesar. Mas há mais nesta copla que o filólogo preferiria não existisse: Por sonho ante vós ponho/ o que eu velando vi. O narrador autodiegético - narrador da própria história - dissera que iria relatar um sonho que tivera depois de o muito desejar, na esperança de nele encontrar a amada e aliviar seu tormento. Foi o que fez (ou pareceu fazer), ao longo de tantas coplas cheias de amor e saudade, em que se ouve a sua voz, depois a voz harmoniosa de Maria a cantar, e também a falar, e finalmente a sua, novamente como narrador, a encerrar o relato de um sonho do qual o leitor não duvidara em nenhum momento. Só então se põe a dúvida: sonho ou realidade? O que eu velando vi,/Por sonho ante vós ponho. (Como não lembrar "Autopsicografia" de Fernando Pessoa?) $\mathrm{O}$ narrador põe por sonho, isto é, finge, como fingidor que é, o que viu, velando. O leitor lê o sonho, que crê ser realidade, a partir do que pouco atrás o pastor afirmara. Mas a copla fecha-se de modo inesperado e, à primeira vista, paradoxal: mas seja pera vós sonho,/pois sonho foi pera mi. Para o leitor, o sonho está, como tal, na estória, não há por que duvidar da sua realidade de sonho; o sujeito lírico é que, num rasgo inesperado, instala a dúvida: seja pera vós sonho/pois sonho foi pera mi. Como se dissesse: Se assim o considerei, eu, o criador da estória oriunda da história, assim o considerareis vós.

Toda esta estória de amor, em versos só aparentemente simples, nos quais se retrata um idílio bucólico decorrido em meio à natureza, constitui um dos momentos mais plenamente realizados da poesia da medida velha em Portugal. Marcou-me, pois, a sua descoberta na universidade. E, por mais que soubesse e saiba que o espaço em que decorre a sua estória não é fixo, que, ao contrário, acompanha o deslocamento de seus heróis, o que me ficou e permanece é o espaço inicial, localizado Antre Sintra, a mui prezada, / e serra de Ribatejo/ que Arrábida é chamada, a serra que conheci e de meus próprios 
olhos vi. E amei. Por que a vi, ou por que nela reencontrei a que, há mais de meio século, figura nos mapas da minha memória?

Dou-me conta neste momento de que não saí da Arrábida. Ainda não me desprendi das areias de Portugal. E, no entanto, uma frota de 13 naus aguarda a hora de partir da praia do Restelo. Desta vez, a ordem será minha para que se inicie a única viagem agora possível, a que se fará nas águas do meu texto, ponto de confluência de outras águas mais antigas, que a alimentam com a sua antiga experiência de chegadas e partidas, de perdas e achamentos. Convido-vos a vir comigo na frota de Pedro Álvares Cabral, senhor de Belmonte, alcaide-mor de Azurara, descendente de uma família das mais nobres e antigas do reino e ainda não descobridor do Brasil, pois ainda estamos em Lisboa. E cá estamos porque el-rei D. Manuel ainda hesita na escolha do comandante da expedição: Vasco da Gama ou Cabral? Por fim, aos 15 de fevereiro de 1500, uma carta régia nomeia Pedro Álvares Cabral para exercer a capitania-mor da esquadra que então se aprestava para a Índia. Quem mo ensina é um brasileiro, o almirante e historiador Max Justo Guedes, num lúcido - e para mim, aprendiz de história, esclarecedor - ensaio sobre o descobrimento do Brasil, publicado no belíssimo número da revista Oceanos, subintitulado "O achamento do Brasil".

Acrescenta Jorge Couto, em excelente ensaio que àquele se segue, que, em documento redigido entre meados de Setembro e 4 de Novembro de 1499, era Vasco da Gama o indigitado para o cargo de capitão-mor, e Bartolomeu Dias [o] responsável pela flotilha de caravelas destinada a Sofala. Deverá ter, pois, causado surpresa a nomeação de Cabral para o cargo máximo da armada que zarpa de Belém a 9 de Março de 1500, levando Bartolomeu Dias, mas não Vasco da Gama. Passa ao largo das Canárias, alcança Cabo-Verde, transpõe, à distância, o arquipélago de Fernando de Noronha, o cabo São Roque. Por volta do dia 18 de Abril, a armada encontrar-se-ia na altura da Bahia de Todos-os-Santos, onde o vento favorece a aproximação da terra. $\mathrm{Na}$ terça-feira, 21, aparecem os seus primeiros sinais, diz-nos o nunca assaz louvado escrivão Pero Vaz de Caminha, que passo a citar, ipsis litteris:

A 22 de Abril toparam, pela manhã, com aves, a que chamam fura-buchos [...] e a horas de véspera tiveram vista de terra, isto é, primeiramente dum grande monte, mui alto e redondo, e doutras serras mais baixas a sul dele e de terra chã com grandes arvoredos, ao qual monte alto o capitão pôs nome o Monte Pascoal e à terra Terra de Vera Cruz.

Por que cito este passo, talvez o mais conhecido de todos aqueles que se interessam pela história dos nossos países? Porque nele se contém a descrição da primeira visão que da terra recém-achada tiveram os portugueses, como que recortada pelo óculo de alcance do cronista: um grande monte, mui alto e redondo, e doutras serras mais baixas a sul dele e de terra chã com grandes arvoredos, um bocado que se pode apreender numa vista de olhos, de uma determinada posição. Se a nau estivesse voltada mais à direita ou mais à esquerda, a visão seria outra. Insisto neste ponto, sob a influência do ensaio, já atrás referido, de Max Justo Guedes que, na sua dupla condição de marinheiro e historiador atilado, empenhou-se em buscar uma prova visível da direção em que a nau se colocava em relação à nova terra, questionando-se: 
Se Cabral, ao encontrar, em latitude próxima aos $17^{\circ} \mathrm{S}$, condições de vento que lhe permitiriam, sem problemas, prosseguir na rota da Índia, julgou propícia a ocasião para reconhecer a terra cujos sinais de proximidade tinha desde o dia anterior, é natural que mandasse rumar directamente a oeste. Estávamos em abril, já iniciada a monção de sul, que deve ter alterado algo este rumo.

Tentou, por várias vezes, aproximar-se do ponto do qual, segundo Pero Vaz de Caminha, se avistava o monte e as serras mais baixas ao sul dele, para tirar conclusões sobre a direção em que se teria movido a nau. Da primeira vez, vinha num navio da marinha, cujo comandante relutou em aproximar-se da costa; de outras, sobrevoou em avião, o que lhe impedia a observação. Finalmente, conseguiu um helicóptero da Marinha e

Com a aeronave voando na altura aproximada do cesto de gávea de uma nau cabralina, efectuei múltiplas aproximações em rumos que, de quarta $\left(11^{\circ} 15^{\prime}\right)$ em quarta, cobriram todo o sector em que o Monte Pascoal era visto, desde sudoeste até noroeste. O resultado foi mais elucidativo que minha expectativa, já que só avistei o monte e as "serras mais baixas ao sul dele"da maneira descrita por Caminha quando a aproximação se fez vindo exactamente de sueste!

Volto a perguntar (numa pergunta meramente retórica): por que buscava o almirante, tão insistentemente, comprovar o rumo da nau? Porque estava altamente interessado em trazer elementos que corroborassem a tese da intencionalidade do descobrimento do Brasil, em cuja discussão, encarece, têm corrido rios de tinta. Quase ao fim do ensaio, sintetiza a sua posição no debate:

A conclusão lógica, a meu ver, é que a arribada foi proposital, intencional, para reconhecer a terra suspeitada já em Portugal e convenientemente situá-la para apoio na rota da Índia e não um encontro casual quando a armada passava a largo da costa.

Tendo havido vista de terra na quarta-feira, 22 de Abril, ao fim da tarde ancoramos a uma distância de 6 léguas, onde passamos a noite; na quinta-feira 23, pela manhã, fizemos vela na direção da terra, lançando âncora, pelas 10 horas, na foz de um rio. À noite ventou tão forte que desviou as naus do lugar onde estavam ancoradas; na sexta-feira, 24, pelas 8 horas da manhã, mandou o capitão levantar âncoras e faz̧er vela, em busca de alguma abrigada e bom pouso. Seguindo pela costa, acharam os ditos navios pequenos um arrecife com um porto dentro, muito bom e muito seguro, com uma mui larga entrada. E meteram-se dentro e amainaram. E as naus arribaram sobre eles. É o que nos informa, com clareza, método e minúcia, o benemérito escrivão de Cabral, primeiro notário do Brasil, que lhe redigiu a certidão de nascimento. Estamos, pois, em Porto Seguro, o outro extremo da nossa navegação.

Como espero que tenhais notado, assumi, à imitação de Caminha, a primeira pessoa do plural, pois vos convidara a vir conosco - Cabral e seus navegantes. Dissera-vos que a nossa viagem se faria nas águas do texto que teci e vou arrematando. Novamente, a palavra de ordem será minha, a dizer que não partamos, mas permaneçamos na terra achada ou descoberta, tanto faz, não mais em grupos diferenciados pela cor, pela cultura, pela língua, não mais aborígenes e estrangeiros, mas descendentes brasileiros de uns e outros, e de muitos outros mais que chegaram mais tarde, de outras terras, línguas e 
culturas, miscigenados todos, misturados num amálgama em que são cada vez menos discerníveis os elementos que o compõem, somando-se e potencializando-se reciprocamente.

Como Crisfal, sonhei o meu sonho e, como ele, o narrei. Ele, com a voz eleita de um grande poeta. Eu, como pude. Perdoai.

$* * * *$

A minha viagem termina aqui; a verdadeira viagem de Cabral terminou em Lisboa, de volta da Índia: Aos 23 de Junho reentrou no Tejo a Anunciada e, na sequência, Cabral e Pero de Ataide; finalmente, chegaram Nicolau Coelho, Sancho de Tovar e Diogo Dias. E acrescenta o almirante Max Justo Guedes: Concluia-se assim a viagem que, parecendo momentaneamente desastrosa, se transformaria no maior feito da gente lusa: o Descobrimento do Brasil!

\section{Notas}

1 Convidada pela colega Orna Messer Levin a a fazer parte do grupo de amigos que homenagearão Vilma Arêas pelos seus 70 anos, disse-lhe, sem hesitar, um sim convicto. Não poderia ser outra a minha resposta, pelo que Vilma significa para mim, desde que foi minha aluna na Graduação em Letras Anglo-Germânicas, na UFRJ, onde se distinguiu pela sua rica personalidade, o que me levou a convidá-la para nossa assistente nessa Universidade e a seguir na PUC-Rio. Nesta, cursou a Pós-Graduação, tendo apresentado uma excelente dissertação de Mestrado, por mim orientada, sobre um autor até então pouco conhecido, que tínhamos estudado num dos cursos que lá ministrei - Augusto Abelaira. Depois, no seu Concurso de Livre-Docência na UFF, em que fiz parte da banca, a cujas argüições respondeu brilhantemente. Finalmente, mais uma vez fazendo parte de banca examinadora, em seu belo concurso para Titular da UNICAMP. Paralelamente, acompanhei de longe o seu curso de Doutorado na USP, tal como a sua caminhada de ficcionista.

Dito o sim, pensei: Que tipo de texto agradaria à minha amiga - que, dividida entre o magistério e a pesquisa, de um lado, e a criação ficcional, de outro -, poderia avaliar o carinho com que busquei escolher, entre o já escrito, algo que me aproximasse do seu duplo caminho, eu, que apenas por um deles trilhei, com raras exceções? $\mathrm{E}$ ocorreu-me uma conferência que fizera, em 2000, no encerramento dos Cursos da Arrábida - mescla de história e estória, feita esta de alguma lenda e de bocados de imaginação.

São muitos anos do que eu chamaria convivência à distância, em que nunca nos perdemos de vista. São muitos anos de amizade cada vez mais segura, de afeto recíproco. O convite de Orna, que agradeço, deu-me a oportunidade de escrever o que aqui fica, como se fosse uma fala em voz alta, para que se ouça.

2 NASCENTES, Antenor. Dicionário Filológico da Lingua Portuguesa, $1^{\mathrm{a}}$ edição. Rio de Janeiro: Francisco Alves, 1952-1955.

* Os organizadores deste número da revista agradecem a colaboração de Orna Messer Levin. 